\title{
Erratum to: Chemokine CXCL14/BRAK transgenic mice suppress growth of carcinoma cell transplants
}

\author{
Kazuhito Izukuri · Kenji Suzuki • \\ Nobuyuki Yajima $\cdot$ Shigeyuki Ozawa \\ Shin Ito $\cdot$ Eiro Kubota $\cdot$ Ryu-Ichiro Hata
}

Published online: 24 August 2010

(C) Springer Science+Business Media B.V. 2010

\section{Erratum to: Transgenic Res \\ DOI 10.1007/s11248-010-9384-7}

In this article, xenografts should read transplants (as shown in the title).

The online version of the original article can be found under doi:10.1007/s11248-010-9384-7.

K. Izukuri · N. Yajima $\cdot$ S. Ito · R.-I. Hata $(\bowtie)$ Oral Health Science Research Center/Department of Biochemistry and Molecular Biology, Kanagawa Dental College, 82 Inaoka-cho, Yokosuka 238-8580, Japan

e-mail: ryuhata@gmail.com

K. Suzuki $\cdot$ S. Ozawa $\cdot$ E. Kubota Oral Health Science Research Center/Department of Oral and Maxillofacial Surgery, Kanagawa Dental College, 82 Inaoka-Cho, Yokosuka 238-8580, Japan 